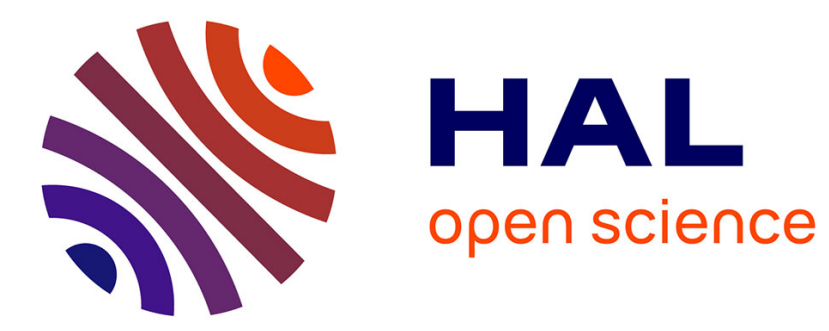

\title{
Eyring acceleration model for predicting calendar ageing of lithium-ion batteries
}

Eduardo Redondo-Iglesias, Pascal Venet, Serge Pelissier

\section{To cite this version:}

Eduardo Redondo-Iglesias, Pascal Venet, Serge Pelissier. Eyring acceleration model for predicting calendar ageing of lithium-ion batteries. Journal of Energy Storage, 2017, 13, pp.176-183. 10.1016/j.est.2017.06.009 . hal-01575005

\section{HAL Id: hal-01575005 \\ https://hal.science/hal-01575005}

Submitted on 17 Aug 2017

HAL is a multi-disciplinary open access archive for the deposit and dissemination of scientific research documents, whether they are published or not. The documents may come from teaching and research institutions in France or abroad, or from public or private research centers.
L'archive ouverte pluridisciplinaire HAL, est destinée au dépôt et à la diffusion de documents scientifiques de niveau recherche, publiés ou non, émanant des établissements d'enseignement et de recherche français ou étrangers, des laboratoires publics ou privés. 


\title{
Eyring acceleration model for predicting calendar ageing of lithium-ion batteries.
}

\author{
Eduardo Redondo-Iglesias ${ }^{\mathrm{a}, \mathrm{b}, *}$, Pascal Venet $^{\mathrm{b}}$, Serge Pelissier $^{\mathrm{a}}$ \\ ${ }^{a}$ Univ Lyon, IFSTTAR, AME, LTE, 69500 Bron, France \\ ${ }^{b}$ Univ Lyon, UCB Lyon 1, AMPERE UMR CNRS 5005, 69100 Villeurbanne, France
}

\begin{abstract}
Modelling of lithium-ion batteries calendar ageing is often based on a semi-empirical approach by using, for example the Arrhenius acceleration model. Our approach is based on Eyring acceleration model, which is not widely used for electrochemical energy storage components. Parameter identification is typically performed without taking into account the state-of-charge $(S o C)$ drifting. However, even in rest condition, battery cells' $S o C$ drifts because of capacity losses (self-discharge and capacity fade). In this work we have taken into account the $S o C$ drift during calendar ageing tests. For this, we considered available capacity (Ah) instead of $S o C(\%)$ as ageing factor. Then, the analytical solution of the problem leads to the use of the Lambert $W$ function in the model formulation. Simulation results show that Lambert-Eyring model is more accurate and allows a reduction in the number of parameters to be identified.
\end{abstract}

Keywords: Lithium-ion battery, reliability, accelerated ageing, modelling, Eyring Law, Lambert W function

\section{NOMENCLATURE}

$\begin{array}{ll}S o C & \text { State of Charge } \\ T & \text { Temperature } \\ Q_{0} & \text { Initial capacity } \\ Q & \text { Current capacity } \\ Q_{a} & \text { Available capacity } \\ Q_{d} & \text { Used capacity } \\ Q_{s d} & \text { Self-discharge (reversible capacity loss) } \\ Q_{L} & \text { Capacity fade (irreversible capacity loss) }\end{array}$

\section{Introduction}

During the last decade, electric vehicles (EV) and 5 hybrid electric vehicles sales have grown from 0.1 to $3 \%$ in France [1]. However, the low range and high purchasing price of EV's are the main obstacles to their market penetration. Range and price are directly related to the battery size which is the 10 most expensive component of an electric vehicle. Currently, car manufacturers have found a compromise between price and range that fixes typically the range between 100 and $200 \mathrm{~km}$ for a purchasing

\footnotetext{
*Corresponding author: eduardo.redondo@ifsttar.fr
}

price (including batteries) from 20 to $40 \mathrm{k} €$. Bat15 tery size of those vehicles vary from 16 to $24 \mathrm{kWh}$.

Electric vehicles can contribute to a cleaner mobility, but for this, the whole life cycle must be optimized in order to be less resource consumer and less waste producer than thermal vehicles.

20 Energy management of the vehicle is often optimized with an energy economy aim, but it can also be done for extending the battery longevity. The elaboration of this kind of strategies requires reliable and accurate ageing models.

${ }_{25}$ In this paper, calendar ageing of lithium-ion LFP/C cells has been modelled. Calendar ageing seems to be predominant in batteries used in applications such as electric vehicle. LFP cells offer high durability, power and safety, which represent so three crucial performances for transportation applications.

A classical approach of model parameter identification consists on a step by step identification: first step consists of identifying the temperature $(T)$ 35 influence and then the second step is for the stateof-charge $(S o C)$ influence. For this, every factor (T and $S o C$ ) must be considered as being constant.

During calendar ageing tests, constant tempera-

July 3, 2017 
ture is easily driven because battery cells are in rest 40 condition and no heat is emitted by them. However, battery cells' $S o C$ is not constant: $S o C$ drifts over time because of capacity losses.

Consequently, $S o C$ drift may be considered from the parameter identification phase in order to im45 prove the ageing model accuracy. The chosen formulation in this work relies on the Eyring acceleration law [2]. This law allows a global approach where all parameters can be identified in a single step.

\section{2. Calendar ageing}

Calendar ageing of a battery cell is the degradation of its performances while being in rest condition, that is when no current is supplied or absorbed by this cell. This type of ageing must considered in ${ }_{55}$ transport applications because vehicles are parked $95 \%$ of the time [3].

Calendar ageing yields on ageing mechanisms caused by side reactions between the different chemical substances inside each component of the bat-

${ }_{60}$ tery (electrodes, electrolyte, etc.). Ageing mechanisms of lithium-ion batteries are numerous, complex and can interact with each other [4].

As on battery cells the main ageing mechanisms lie on chemical reactions, the battery per-

65 formances degrade over time as these reactions advance. Thus, Arrhenius-like laws are commonly used to explain the thermal stress influence on performances. Equation 1 is a general form for a performance $(y(t))$ degrading over time under a ther70 mal stress (T) using the modified Arrhenius law. The performance $y(t)$ can be the internal resistance (power fade) [5-8] or the capacity fade [9-11] with $T$ the absolute temperature (in K), $A$ the preexponential factor, $E_{a}$ the activation energy for the 75 reaction (in $\mathrm{eV}$ ), $k$ the Boltzmann constant and $f(t)$ the time degradation function of $y(t)$ considered.

$$
y(t)=A T^{n} e^{(E a / k T)} f(t)
$$

The Eyring law is also used on reliability studies [2] for example for mechanical components 80 [12]. This law extends the Arrhenius law to other stress factors $S_{i}$ such as pressure, current, voltage, etc. Equation 2 is a general form for a performance $(y(t))$ degrading over time under two type of stresses ( $\mathrm{T}$ and $S_{i}$ ) using the Eyring law. In 130 85 the Eyring law each additional stress is added to the exponential function beside the thermal stress term $\left(E_{a} / k T\right)$. The direct influence of a stress is $B_{i} S_{i}$ and $C_{i} S_{i} / k T$ represent an interaction term between temperature and $S_{i}$ where $B_{i}, C_{i}$ are stress90 dependent constants.

$$
y(t)=A T^{n} e^{\left(E a / k T+B_{i} S_{i}+C_{i} S_{i} / k T\right)} f(t)
$$

In this paper, we have modelled calendar ageing of A123 LFP/C cells (2.3Ah) from SIMCAL project [13]. The main calendar ageing mechanism in this type of cells is SEI (Solid Electrolyte Interface) formation [14]. The consequence of this ageing mechanism is the capacity fade due to a loss of lithium inventory.

In order to facilitate the results comparison, all capacity measurements and simulation are expressed relative to initial capacity (p.u.).

\subsection{Accelerated ageing tests in SIMCAL project}

Accelerated ageing tests were carried out in order to show up the ageing mechanisms responsible of 05 battery degradation. These tests consist in putting battery cells to different levels of use constraints. The collected results can be used afterwards to establish remaining useful life or performance evolution laws.

In the case of calendar ageing, two factors have been identified as being responsible of battery degradation: temperature $(T)$ and state-ofcharge $(S o C)$. In SIMCAL project [13], six technologies of batteries (one $\mathrm{NMC} / \mathrm{C}$, one $\mathrm{NCA} / \mathrm{C}$, one $\mathrm{LMO} / \mathrm{NMC}$ blended/C and three $\mathrm{LFP} / \mathrm{C}$ ) were tested to study the influence of SoC and temperature as ageing factors. Target values of factors are 30,45 and $60^{\circ} \mathrm{C}$ for temperature and 30, 65 and $100 \%$ for SoC. Each couple of values (T, SoC) was assigned to three different cells to improve the representativeness of the results. Cells' performances were periodically measured by the means of RPTs (Reference Performance Tests) at $25^{\circ} \mathrm{C}$. The RPT protocol consisted in:

- Full charge/discharge cycle at $1 \mathrm{C}$ rate for capacity measurement

- Electrochemical Impedance Spectroscopy (EIS) and time response to pulse profiles at different values of SoC

In this work, we focused the analysis to one LFP/C technology and exploited only the capacity measurements. 
Figure 1 shows the capacity loss evolution $\left(Q_{L}\right)$ of A123 cells under ageing tests from SIMCAL

project. In this figure the temperature influence is clearly perceptible: if cells are grouped by $S o C$ level, cell degradation is greater at higher temperatures (that is, degradation rate is higher for $60^{\circ} \mathrm{C}$ than for $45^{\circ} \mathrm{C}$ and than for $30^{\circ} \mathrm{C}$ for each $S o C$ level).

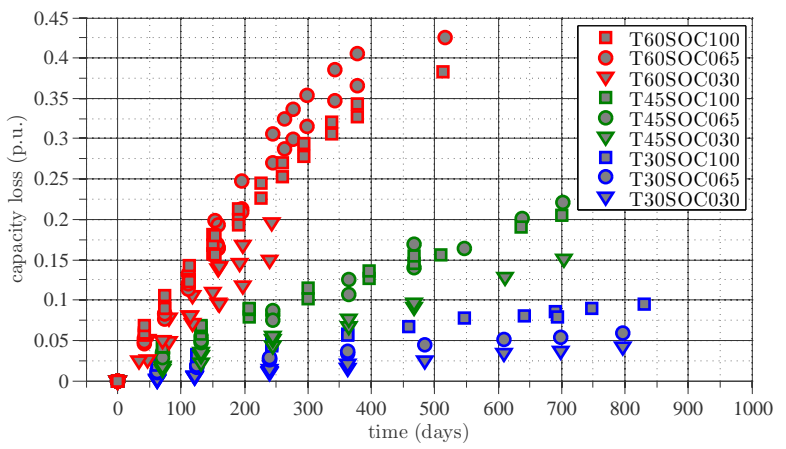

Figure 1: Capacity loss of A123 cells from SIMCAL project.

Nonetheless, the reciprocity of this sentence is not always true: the degradation rate is not always higher at higher $\mathrm{SoC}$ levels. At $30^{\circ} \mathrm{C}$ cell degradation is greater when $S o C$ is higher, that is degradation at $S o C 100 \%$ is higher than when $S o C$ is $65 \%$ and $30 \%$. However, at $45^{\circ} \mathrm{C}$, degradation at $S o C 100 \%$ is similar than when $S o C$ is $65 \%$. Even at $60^{\circ} \mathrm{C}$, degradation at $S o C 100 \%$ is lower than when $S o C$ is $65 \%$. This behaviour seems to be atyp150 ical and highlights a strong interaction between the ageing factors $(T, S o C)$.

\subsection{SoC drift during ageing tests}

When a battery cell is at rest condition, its energy (capacity) and power (impedance) performances change by ageing. Cell's $S o C$ changes also. $S o C$ drift of a cell in rest is caused by capacity losses. Capacity losses are either reversible, due to self-discharge; either irreversible, due to degradation mechanisms.

$S o C$ (expressed in p.u.) is defined in equation $3{ }_{205}$ as the ratio between available quantity of charge $\left(Q_{a}\right)$ and current capacity $(Q)$ at every moment $(\mathrm{t})$ :

$$
S o C(t)=\frac{Q_{a}(t)}{Q(t)}
$$

$Q_{a}$ can be expressed as a function of discharged 210 quantity of charge $\left(Q_{d}\right)$ since the last full charge and self-discharge $\left(Q_{s d}\right)$ as shown in equation 4:

$$
Q_{a}(t)=Q(t)-Q_{d}(t)-Q_{s d}(t)
$$

On the other hand, cell capacity change according to ageing (equation 5), $Q_{0}$ and $Q_{L}$ are respectively initial capacity and irreversible capacity loss:

$$
Q(t)=Q_{0}-Q_{L}(t)
$$

These three equations lead to the following expression for $S o C$ evolution:

$$
S o C(t)=\left(1-\frac{Q_{d}(t)+Q_{s d}(t)}{Q_{0}-Q_{L}(t)}\right)
$$

Equation 6 highlights that $S o C$ is not constant during the rest phase between two RTPs and that $S o C$ drift occurs during ageing tests. The drift is mainly caused by capacity fade $\left(Q_{L}\right)$ as selfdischarge $\left(Q_{s d}\right)$ is relatively low and often negligible for lithium-ion batteries. With ageing, $Q_{L}$ increases and to maintain $S o C$ constant during the test, one should change the value of $Q_{d}$. $Q_{d}$ is the quantity of charge discharged after a RPT from the cell at SoC $100 \%$ to put it at the target SoC (65 or $30 \%)$. For commodity reasons the same value of $Q_{d}$ is used all along the duration of the experiments. Otherwise, one should compute a new value of $Q_{d}$ for each cell after each RTP which is practically infeasible when hundreds of cells are tested. For this reason a cell supposed to be stored for instance at SoC $65 \%$ is effectively stored at this value only at the beginning of the experiments. As soon as an irreversible capacity fade occurs, the storage SoC drifts.

Figure 2 shows $S o C$ drift of battery cells as a function of irreversible capacity losses $\left(Q_{L}\right)$ in the absence of self-discharge $\left(Q_{s d}=0\right)$. In this figure, $S o C$ drift is calculated as in equation 6 for three different initial values of $S o C$ (30, 65 and 100\%), so $Q_{d}$ is respectively $0.7,0.35$ and 0 p.u. Therefore, even if no self-discharge takes place, $S o C$ inevitably drifts away from the desired $S o C$ level. This $S o C$ drift is a source of imprecision if it is not taken into account when identifying the model parameters.

$S o C$ drift is minimal when target $S o C$ is $100 \%$. Experimental data reveal that $S o C$ drift in $\mathrm{SoC} 100$ cells was lower than $3 \%$.

\section{Ageing modelling}

As explained above, lithium-ion battery ageing depends mainly of the couple $(T, S o C)$. During the ageing tests, each cell has been stored at couple 


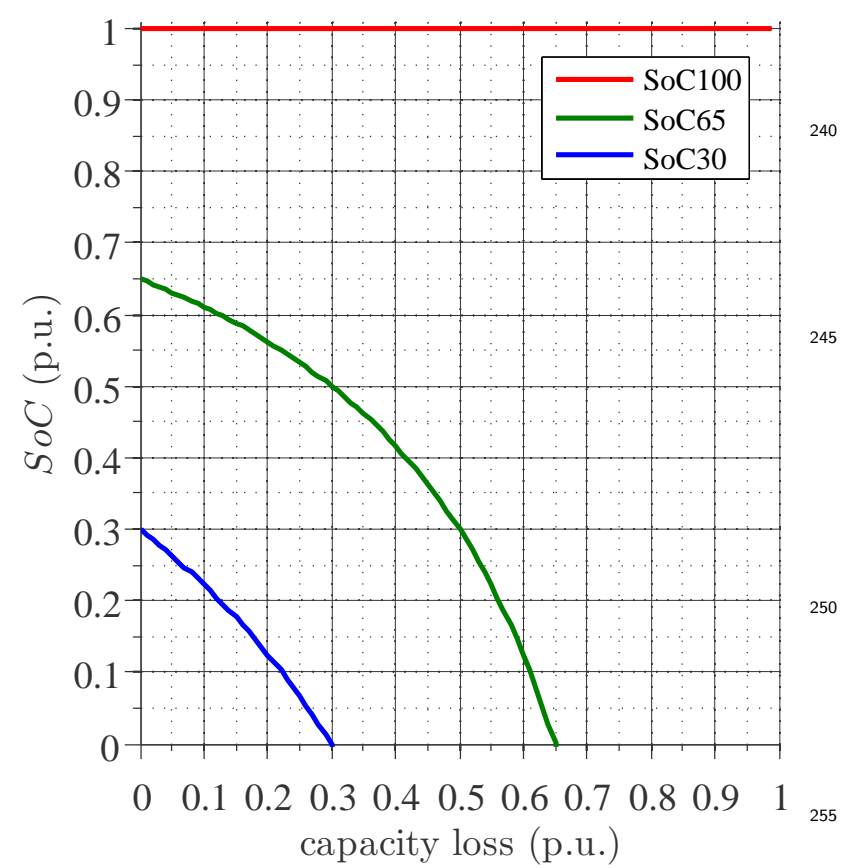

Figure 2: SoC drift according to expression 6 with $Q_{s d}=0$.

of values $(T, S o C)$, but $S o C$ drifts mainly because of capacity losses $\left(Q_{L}\right)$.

At first, in order to model the battery ageing, a the battery degradation must be chosen. This variable can be, for example, the cell impedance $[5,15]$ or the derivative of capacity over time $\left(\frac{d Q_{L}}{d t}\right)[16]$. In this work, we have chosen to model the capacity fade evolution $\left(Q_{L}\right)$ which is the key parameter in EV applications.

Equation 7 is a generic example of $Q_{L}$ ageing model as a function of t, $T$ and $S o C$ where the ageing factors $(T, S o C)$ are decoupled from time [17]:

$$
Q_{L}(t, T, S o C)=C_{A}(T, S o C) \cdot f(t)
$$

This equation implies that $Q_{L}$ evolution for every cell follows the same shape $(f(t))$ independently of the value of $\mathrm{T}$ and $S o C$. $\mathrm{T}$ and $S o C$ will change the size of the shape with an acceleration coefficient $\left(C_{A}\right)$.

Typically, the chosen $f(t)$ is a power of time $\left(t^{z}\right)$ [5], an exponential function [15] or a composition of time functions [18], for example $(t+\sqrt{t})$.

\subsection{Ageing model without taking into account the SoC drift}

The classical approach to ageing modelling consists in expressing $C_{A}$ with an Arrhenius expression
$[5,6]$. Pre-exponential factor $(A)$ and activation energy $\left(E_{a}\right)$ of the Arrhenius law may change in terms of the other ageing factors. So, for calendar ageing, these two parameters are expressed as a function of $S o C: A=A(S o C), E_{a}=E_{a}(S o C)$.

In this work the chosen shape function $f(t)$ is $t^{z}$ with a fixed $z$ independently of $\mathrm{T}$ and $S o C$. In this paper the model has been studied with two different values of $z$ : 0.5 and 1. Equation 8 is the ageing model general equation, where $k$ is the Boltzmann constant.

$$
Q_{L}(t, T, S o C)=A(S o C) \cdot e^{\left(-\frac{E_{a}(S o C)}{k \cdot T}\right)} t^{z}
$$

Once the model general equation is established, the next step consists in identifying the parameter values $A$ and $E_{a}$ at each $S o C$ level. This is only possible if $S o C$ is assumed to be constant $(100,65$ or 30) for each cell throught the ageing tests. This is equivalent to model separately the cells corresponding to each $S o C$ (that is, to find an ageing model for each $S o C$ level).

Figure 3 shows three couples of values $\left(A, E_{a}\right)$ identified for two values of $z$.
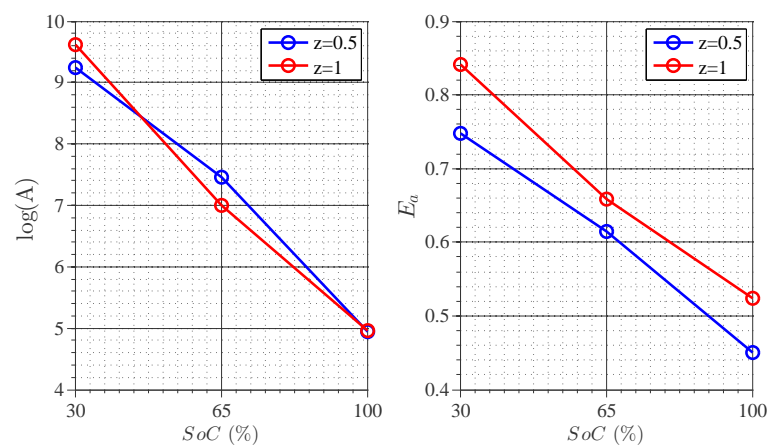

Figure 3: Arrhenius parameter identification as a function of $\mathrm{SoC}$.

At the end of the first step, we have three ageing models that depend of temperature; one model for each $S o C$ level $(30,65,100)$, characterized by their parameter values: $\left(A_{30}, E_{a 30}\right),\left(A_{65}, E_{a 65}\right)$ and $\left(A_{100}, E_{a 100}\right)$.

Second step consists in aggregating these three models in only one model and extrapolating in the whole domain of $S o C(0-100)$. Figure 3 shows that $\log (A)$ and $E_{a}$ are mainly linearly dependent of $S o C$. So, a linear regression can be performed on the previously identified values to obtain the parameters $A_{0}, B_{s}, E_{a 0}$ and $C_{s}$ :

$$
\log (A(S o C))=\log \left(A_{0}\right)+B_{s} \cdot S o C
$$




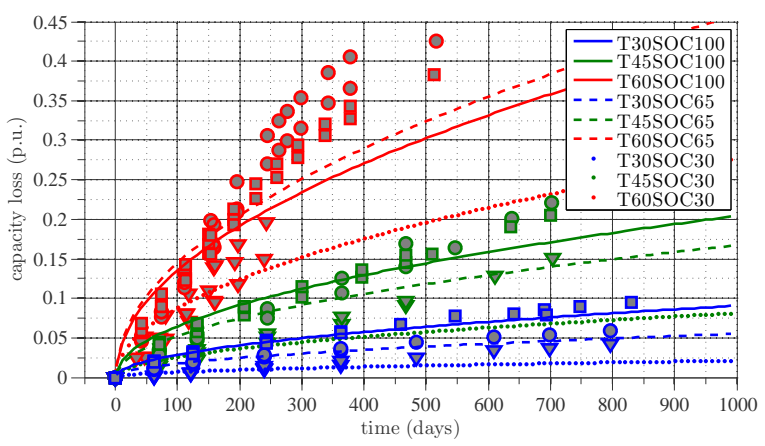

(a) Model $1(z=0.5)$.

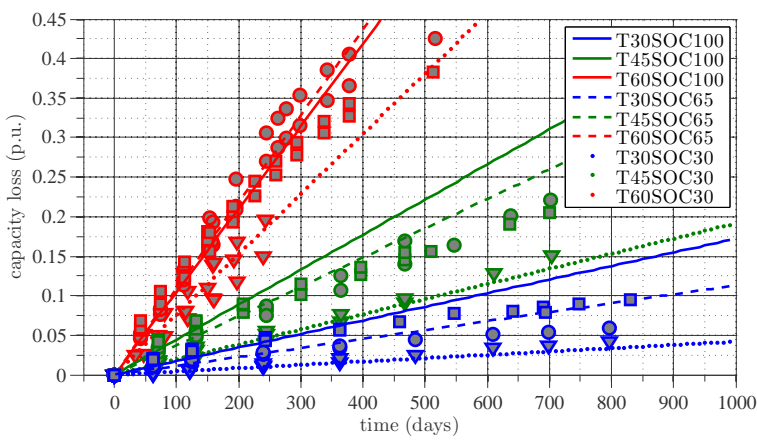

(b) Model 1' $(z=1)$.

Figure 4: Simulation results of the model without taking into account the $S o C$ drift (factors: $T, S o C$ ). Caption for experimental points are the same that in figure 1.

$$
\begin{aligned}
& A(S o C)=A_{0} e^{B_{s} \cdot S o C} \\
& E_{a}(S o C)=E_{a 0}+C_{s} \cdot S o C
\end{aligned}
$$

By replacing 10 and 11 in 8, we obtain equation 12:

$$
Q_{L}(t, T, S o C)=A_{0} e^{B_{s} \cdot S o C} \cdot e^{\left(-\frac{E_{a 0}+C_{s} \cdot S o C}{k \cdot T}\right)} t^{z}(12)^{20}
$$

The identification results are collected in table 1 (model 1: $z=0.5$ and model 1': $z=1$ ). For each linear regression, the coefficients of determination $\left(r^{2}\right)$ are higher than 0.99 , independently of ${ }_{325}$ the value of $z$.

Figure 4 illustrates the simulations results of the ageing model compared to measurements. When the chosen shape function is $\sqrt{t}(z=0.5,4 \mathrm{a})$, model generally underestimates ageing; on the contrary, the simulations are rather divergent when $z=1$ (linear evolution of capacity fade over time, $4 \mathrm{~b}$ ).

\subsection{Ageing model taking into account the SoC drift ${ }^{330}$}

When one ageing acceleration factor, $S o C$, is variable over time, the parameter identification of
Table 1: Identified parameter values: models 1 and 1'.

\begin{tabular}{|c|c|c|c|c|c|}
\hline model & $\begin{array}{c}\boldsymbol{z} \\
(\text { no units) }\end{array}$ & $\begin{array}{c}\boldsymbol{A}_{\mathbf{0}} \\
\left(\text { p.u. } / \text { day }^{z}\right)\end{array}$ & $\begin{array}{c}\boldsymbol{B}_{\boldsymbol{s}} \\
(\text { no units })\end{array}$ & $\begin{array}{c}\boldsymbol{E}_{\boldsymbol{a} \mathbf{0}} \\
(\mathrm{eV})\end{array}$ & $\begin{array}{c}\boldsymbol{C}_{\boldsymbol{s}} \\
(\mathrm{eV})\end{array}$ \\
\hline 1 & 0.5 & $1.65 \cdot 10^{11}$ & $-6.16 \cdot 10^{-2}$ & 0.880 & $-4.24 \cdot 10^{-3}$ \\
\hline $1^{\prime}$ & 1 & $3.22 \cdot 10^{11}$ & $-6.64 \cdot 10^{-2}$ & 0.969 & $-4.52 \cdot 10^{-3}$ \\
\hline
\end{tabular}

the model is not feasible in several steps as previously. The model general equation must be expressed as a function of all the ageing factors before the identification phase, in order to perform a one single step parameter identification. For this reason, we have decided to use the Eyring model.

Eyring law [2] is an extension of Arrhenius law 300 [19] (temperature dependent) to other stress constraints $S_{i}$. Eyring formulation has already been used to model the remaining useful life of materials and mechanical components [12], but is not still widely used for electrochemical energy storage systems. Some recent works propose the Eyring model to express the ageing laws of supercapacitors $[20,21]$ and batteries $[17,22]$.

For supercapacitors and other electrical components, the chosen ageing factors are mainly temperature and voltage $(T, U)$ meanwhile ageing modelling of batteries is expressed as a function of the state-of-charge $(S o C)$ instead of the voltage.

When taking into account the $S o C$ drift, we realize that $S o C$ dependence with capacity loss $\left(Q_{L}\right)$ is not linear and could lead to an inextricable formulation. That is the reason why we have proposed available capacity $\left(Q_{a}\right)$ instead of $S o C$ as ageing factor because of its linearity relation with $Q_{L}$, as indicated by equations 4 and 5 . Shape function $f(t)$ is the same as in the previous section: $t^{z}$.

By taking equation 7 and expressing $C_{A}$ according to an Eyring law depending of $T$ and $Q_{a}$, we obtain the ageing model general equation 13 . However, we will firstly study a particular case of the Eyring law where $n$ and $C$ are 0 (equation 14).

$$
\begin{aligned}
& Q_{L}\left(t, T, Q_{a}\right)=A \cdot T^{n} \cdot e^{\left(-\frac{E_{a}}{k \cdot T}+\left(B+\frac{C}{k T}\right) \cdot Q_{a}\right)} t^{z} \\
& Q_{L}=A \cdot e^{\left(-\frac{E a}{k \cdot T}+B \cdot Q_{a}\right)} t^{z}
\end{aligned}
$$

The global approach to identify the model parameters consists in carrying out a linear regression on equation 15. Equation 15 is obtained by applying the logarithm function to equation 14.

$$
\log \left(Q_{L}\right)=\log (A)-\frac{E_{a}}{k \cdot T}+B \cdot Q_{a}+z \cdot \log (t)(15)
$$


Table 2: Identified parameter values: model 2 (section 3.2), models 3 and 3' (section 3.3).

\begin{tabular}{|c|c|c|c|c|}
\hline model & $\begin{array}{c}\boldsymbol{z} \\
\text { (no units) }\end{array}$ & $\begin{array}{c}\boldsymbol{A} \\
\text { (p.u./day) }\end{array}$ & $\begin{array}{c}\boldsymbol{B} \\
\text { (no units) }\end{array}$ & $\begin{array}{c}\boldsymbol{E}_{\boldsymbol{a}} \\
(\mathrm{eV})\end{array}$ \\
\hline 2 & 1 & $4.35 \cdot 10^{7}$ & 1.104 & 0.719 \\
\hline 3 & 1 & $2.31 \cdot 10^{9}$ & 1.887 & 0.834 \\
$3^{\prime}$ & 1 & $3.35 \cdot 10^{5}$ & 2.154 & 0.611 \\
\hline
\end{tabular}

This equation represents a hyperplane $w=m+$ $n x+p y+q v$ with $w=\log \left(Q_{L}\right), x=\frac{1}{T}, y=Q_{a}$ and $v=\log (t)$. The parameter identification is easily achieved by a multiple linear regression of experimental data. The identification results for $z=1$ are collected in table 2 (model 2 ).

When the parameter values of equation 15 are identified, the next step is to verify the model by comparing simulation to measures. Nevertheless, it is difficult to carry out simulations by using the equation 14 because $Q_{L}$ and $Q_{a}$ are coupled in this equation: it is necessary to decouple both variables.

With the relations 4 and $5, Q_{a}$ can be expressed as a function of $Q_{L}$ (equation 16). By plugging 16 in 14, $Q_{L}$ evolution is no longer dependent of $Q_{a}$ (equation 17).

$$
\begin{aligned}
& Q_{a}=Q_{0}-Q_{L}-Q_{d}-Q_{s d} \\
& Q_{L}=A \cdot e^{\left(-\frac{E a}{k \cdot T}+B \cdot\left(Q_{0}-Q_{L}-Q_{d}-Q_{s d}\right)\right)} t^{z}
\end{aligned}
$$

Finally, by assuming $Q_{s d}=0$ and gathering all the terms depending of $Q_{L}$, expression 18 is obtained, where $A^{\prime}=A \cdot B \cdot e^{B Q_{0}}$.

$$
B \cdot Q_{L}(t) \cdot e^{B \cdot Q_{L}(t)}=A^{\prime} \cdot e^{\left(-\frac{E_{a}}{k \cdot T}-B \cdot Q_{d}\right)} t^{z}
$$

The solution of equation 18 requires to use the Lambert $W$ function. Lambert $W$ function is by definition [23] the solution of the equation $x \cdot e^{x}=y$ with $x, y \in \mathbb{C}$. In our particular case, $y$ is a real number greater than $-1 / e$, so the $W_{0}$ branch of the Lambert $W$ function must be used:

$$
Q_{L}(t)=\frac{W_{0}\left(A^{\prime} \cdot e^{\left(\frac{-E_{a}}{k \cdot T}\right)} \cdot e^{\left(-B \cdot Q_{d}\right)} \cdot t^{z}\right)}{B}
$$

Figure 5a shows the simulation results of the model defined by equation 19 with $z=1$. According to this model, capacity loss trajectory over time will follow the Lambert $W$ function. This result means that in SIMCAL storing conditions (constant $T$ and $Q_{d}$ ), capacity loss evolution is a Lambert function which is between a linear $(t)$ and a squared root of time $\sqrt{t}$.

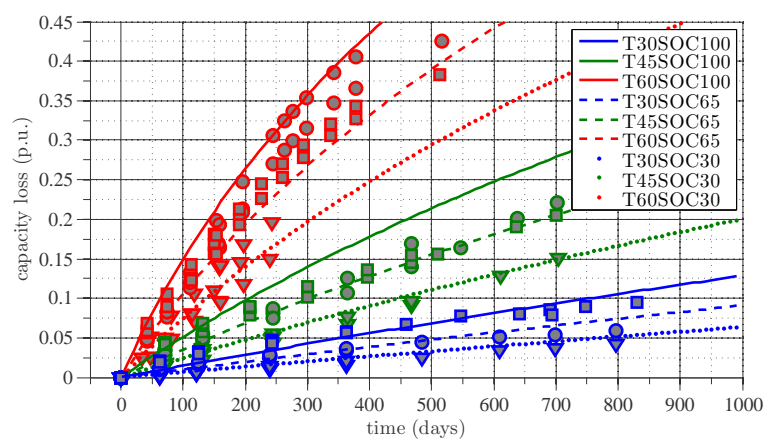

(a) Model 2, section 3.2: the same model used for SoC100, SoC65 and SoC30

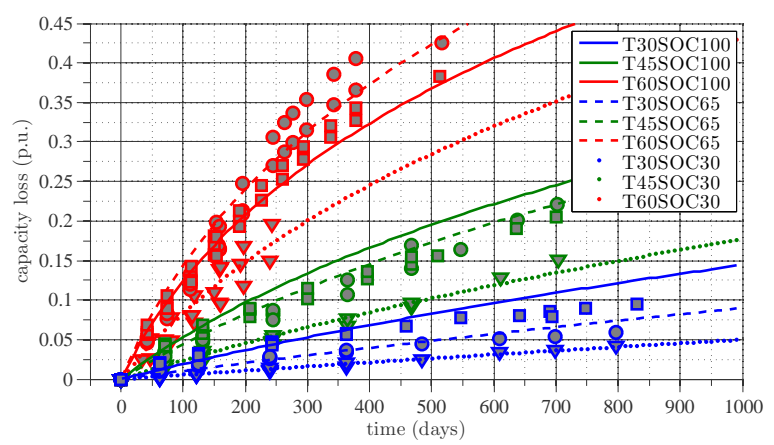

(b) Model 3 (for SoC65 and SoC30) and model 3' (for Soc100), section 3.3 .

Figure 5: Simulation results of the model taking into account SoC drift: (a) same model for all SoC values; (b) one model for Soc65 and Soc30, one model for Soc100. Caption for experimental points are the same that in 1 .

However, atypical behaviour of SoC100 cells can not be taken into account by this model. As explained above, a particular case without interactions between $T$ and $Q_{a}$ has been considered (equation 13 with $C=0$ ).

\subsection{Taking into account of atypical behaviour at SoC100}

To improve the model accuracy the atypical behaviour of SoC100 must be considered. As reported in previous works, ageing rate increase at higher levels of $S o C$. But for the experimental results considered in this paper this is true only at $30^{\circ} \mathrm{C}$. At $45^{\circ} \mathrm{C}$ SoC100 ageing is similar to SoC65 and at $60^{\circ} \mathrm{C}$ ageing is higher for SoC65 cells.

In principle, by adding an interaction term $\frac{C}{k T}$ in the Eyring Law, an additional degree of freedom is added to the model and this would conduct to a better result. The simulations results of the model with interaction term did not show a significant improvement. 
Table 3: Description of the models used in the paper: (a) with constant SoC assumption; (b) taking into account the SoC drift.

(a)

\begin{tabular}{|c|c|}
\hline $\begin{array}{l}\text { Model } \\
\text { number }\end{array}$ & $1 \& 1$ \\
\hline Equation & $Q_{L}=A(S o C) \cdot e^{\left(-\frac{E_{a}(S o C)}{k \cdot T}\right)} t^{z}$ \\
\hline $\begin{array}{r}\text { Stress } \\
\text { factors }\end{array}$ & $T, S o C$ \\
\hline $\begin{array}{c}\text { Model } \\
\text { parameters }\end{array}$ & $A_{0}, B_{S}, E_{a 0}$ and $C_{S}$ \\
\hline $\begin{array}{c}\text { Model } \\
\text { constants }\end{array}$ & $\begin{array}{c}k \text { (Boltzmann constant) } \\
z=0.5 \text { for model } 1 \\
z=1 \text { for model } 1\end{array}$ \\
\hline$S o C$ range & SoC30, 65 and 100 \\
\hline
\end{tabular}

(b)

\begin{tabular}{|c|c|}
\hline $\begin{array}{c}\text { Model } \\
\text { number }\end{array}$ & $2,3 \& 3$ \\
\hline Equation & $Q_{L}=A \cdot e^{\left(-\frac{E_{a}}{k \cdot T}+B \cdot Q_{a}\right)} t^{z}(14)$ \\
\hline $\begin{array}{c}\text { Stress } \\
\text { factors }\end{array}$ & $T, Q_{a}$ \\
\hline $\begin{array}{c}\text { Model } \\
\text { parameters }\end{array}$ & $A, B, E_{a}$ \\
\hline $\begin{array}{c}\text { Model } \\
\text { constants }\end{array}$ & $k$ (Boltzmann constant), z=1 \\
\hline $\begin{array}{c}\text { SoC range } \\
\text { model 2: SoC30, 65 and } 100 \\
\text { model 3: SoC30,65 } \\
\text { model 3': SoC100 }\end{array}$ \\
\hline
\end{tabular}

In fact, the voltage of LFP/C cells exhibits an important discontinuity approximately at SoC70 [24]. This discontinuity is the reflection of a phase change in the negative electrode. This would justify that just one Eyring law is not enough, even if an interaction term is used, to model simultaneously ageing of cells in the whole domain of $S o C$. Therefore, we have modelled SoC100 cells in one side and in the other side SoC65 and SoC30 cells.

The identified model parameter values are collected in the table 2. Model 3 corresponds to SoC65 and SoC30 cells and model 3' to SoC100 cells. Figure $5 \mathrm{~b}$ shows the simulation results compared to measurements.

\section{Results discussion}

Table 3 recapitulates the different models used and their main characteristics. Models 1 and 1' use 430 an Arrhenius law with the pre-exponential term $(A)$
Table 4: Simulation error of four models. Models 1 and 1' (section 3.1), model 2 (section 3.2), models 3 and 3' (section 3.3). The minimal values of each line are underlined while maximal values are in bold.

(a) Mean absolute errors (p.u. of nominal capacity).

\begin{tabular}{|c|c|c|c|c|}
\hline $\mathbf{( T}, \mathbf{S o C})$ & $\begin{array}{c}\mathbf{1} \\
(\mathbf{z}=\mathbf{0 . 5})\end{array}$ & $\begin{array}{c}\mathbf{1} \\
(\mathbf{z}=\mathbf{1})\end{array}$ & $\begin{array}{c}\mathbf{2} \\
(\mathbf{z}=\mathbf{1})\end{array}$ & $\begin{array}{c}\mathbf{3} \text { and 3' } \\
(\mathbf{z}=\mathbf{1})\end{array}$ \\
\hline$(30,30)$ & $\mathbf{0 . 0 0 7}$ & 0.003 & 0.005 & $\underline{0.002}$ \\
$(30,65)$ & $\underline{0.003}$ & 0.008 & 0.005 & 0.005 \\
$(30,100)$ & $\underline{0.004}$ & $\mathbf{0 . 0 1 7}$ & 0.010 & 0.012 \\
$(45,30)$ & $\mathbf{0 . 0 2 6}$ & $\underline{0.006}$ & $\underline{0.006}$ & $\underline{0.006}$ \\
$(45,65)$ & $\mathbf{0 . 0 2 4}$ & 0.015 & $\underline{0.008}$ & 0.011 \\
$(45,100)$ & $\underline{0.011}$ & $\mathbf{0 . 0 3 3}$ & 0.030 & 0.021 \\
$(60,30)$ & $\mathbf{0 . 0 2 1}$ & $\underline{0.015}$ & $\underline{0.015}$ & 0.016 \\
$(60,65)$ & $\mathbf{0 . 0 5 2}$ & $\underline{0.017}$ & 0.034 & 0.024 \\
$(60,100)$ & 0.032 & 0.023 & $\mathbf{0 . 0 4 9}$ & $\underline{0.012}$ \\
\hline mean & $\mathbf{0 . 0 2 0}$ & 0.015 & 0.018 & $\underline{0.012}$ \\
\hline
\end{tabular}

(b) Maximum absolute errors (p.u. of nominal capacity)

\begin{tabular}{|c|c|c|c|c|}
\hline $\mathbf{( T}, \mathbf{S o C})$ & $\begin{array}{c}\mathbf{1} \\
(\mathbf{z}=\mathbf{0 . 5})\end{array}$ & $\begin{array}{c}\mathbf{1} \\
(\mathbf{z}=\mathbf{1})\end{array}$ & $\begin{array}{c}\mathbf{2} \\
(\mathbf{z}=\mathbf{1})\end{array}$ & $\begin{array}{c}\mathbf{3} \text { and 3' } \\
(\mathbf{z}=\mathbf{1})\end{array}$ \\
\hline$(30,30)$ & $\mathbf{0 . 0 2 2}$ & 0.008 & 0.010 & $\underline{0.004}$ \\
$(30,65)$ & $\underline{0.009}$ & 0.032 & 0.015 & 0.015 \\
$(30,100)$ & $\underline{0.012}$ & $\mathbf{0 . 0 4 8}$ & 0.014 & 0.030 \\
$(45,30)$ & $\mathbf{0 . 0 8 2}$ & 0.016 & 0.016 & $\underline{0.015}$ \\
$(45,65)$ & $\mathbf{0 . 0 8 1}$ & 0.040 & $\underline{0.023}$ & 0.028 \\
$(45,100)$ & $\underline{0.034}$ & $\mathbf{0 . 1 0 6}$ & 0.074 & 0.041 \\
$(60,30)$ & $\mathbf{0 . 0 5 9}$ & 0.033 & 0.031 & $\underline{0.030}$ \\
$(60,65)$ & 0.124 & $\mathbf{0 . 1 3 8}$ & 0.089 & $\underline{\underline{0.045}}$ \\
$(60,100)$ & 0.080 & $\mathbf{0 . 1 5 5}$ & 0.130 & $\underline{0.031}$ \\
\hline maximum & 0.124 & $\mathbf{0 . 1 5 5}$ & 0.130 & $\underline{0.045}$ \\
\hline
\end{tabular}

and the activation energy $\left(E_{a}\right)$ depending of $S o C$ to take into account the coupling between temperature and $\mathrm{SoC}$. In these models $\mathrm{SoC}$ assumed constant during the ageing tests. In model 1 the time function is $\sqrt{t}$ whereas in model 1' time variation is linear. Models 2, 3 and 3' use an Eyring law in order to take into account the $\mathrm{SoC}$ drift during the ageing tests. Model 2 attempts to represent the ageing for all values of $S o C$ whereas in models 3 and 3' $S o C$ lower and higher than $70 \%$ are considered separately.

Tables $4 \mathrm{a}$ and $4 \mathrm{~b}$ illustrate the accuracy of each 420 del presented in the previous section. Mean absolute errors (table 4a) show that model 3 is much more accurate than models which do not take into account the $S o C$ drift (40 and $20 \%$ better than model 1 and 1' respectively). For model 2, mean errors are similar than for model 1'.

Nevertheless, when analysing separately the maximum error values at each test condition (table $4 \mathrm{~b}$ ), a real improvement is visible. For example, at $30^{\circ} \mathrm{C}$ maximum error of model 2 is under $2 \%$ for every $S o C$, meanwhile for model 1' it is up to $4.8 \%$. 
Also, for every test condition, except T30SOC30, the maximum error of model 2 is lower than for the model 1. Finally, model 2 needs one fewer parame-

\section{Conclusions}

During calendar ageing tests, every factor should be controlled to keep them constant. The two calendar ageing factors are temperature $(T)$ and stateof-charge $(S o C)$. During calendar ageing tests, cells are put in rest condition (disconnected) at a determined temperature and state-of-charge.

When $T$ and $S o C$ are constant, a step-by-step identification may be conducted. For example, cal- ${ }^{495}$ endar ageing model could be expressed with an Arrhenius based equation. In the first step, the temperature influence is identified and give the Arrhenius parameters $\left(A, E_{a}\right)$. In the second step, each ${ }^{500}$ parameter is studied as a function of $\operatorname{SoC}(A(S o C)$, $\left.E_{a}(S o C)\right)$.

However, $S o C$ is not constant: $S o C$ drifts over time because of reversible and irreversible capacity losses $\left(Q_{s d}\right.$ and $\left.Q_{L}\right)$. SoC drift must be considered from the parameter identification phase.

By taking into account the $S o C$ drift, all the factors $(T, S o C)$ must be considered at the same time. The global approach shown in this work allows to identify all the parameters at the same time but for this we need to develop the equations and to find an analytical solution beforehand.

The ageing model is based on the Eyring law by taking the couple $\left(T, Q_{a}\right)$ as ageing acceleration factors. In this case, the analytical solution of the equation $x \cdot e^{x}=y$ is the Lambert $W$ function.

This novel approach results in a significant improvement of the accuracy of the model compared to the classical approach.

It could be applied to any chemistry of batteries. The need of a discontinuity in ageing laws around 470 SoC 70 may be specific to the LFP.

\section{Aknowledgement}

This work uses data from SIMCAL project. The SIMCAL project (2009-2012) was funded by the French National Research Agency (ANR). SIMCAL partners are CEA, EDF, EIGSI, IFPEN, IFSTTAR, IMS, LEC, LMS-Imagine, LRCS, PSA, RENAULT, SAFT, and VALEO.

\section{References}

[1] CGDD, Immatriculations de véhicules neufs et d'occasion en 2014, http://www. statistiques.developpement-durable.gouv.fr/ transports/r/immatriculations.html?cHash= dba439ca0c990d713bbfbbd716c06395\&tx_ttnews [tt_ news] $=23978(2015)$

URL http://www.statistiques.

developpement-durable.gouv.fr/

transports/r/immatriculations.html?cHash= dba439ca0c990d713bbfbbd716c06395\&tx_ttnews [tt_ news] $=23978$

[2] M. Natrella, al., NIST/SEMATECH e-handbook of statistical methods, NIST/SEMATECH (2010).

URL http://www.itl.nist.gov/div898/handbook/ index.htm

[3] CGDD, enquête nationale transports et déplacements, http://www. statistiques.developpement-durable.gouv.fr/ sources-methodes/enquete-nomenclature/1543/139/ enquete-nationale-transports-deplacements-entd-2008. html (2008).

URL http://www.statistiques.

developpement-durable.gouv.fr/

sources-methodes/enquete-nomenclature/1543/139/ enquete-nationale-transports-deplacements-entd-2008. html

[4] J. Vetter, P. Novák, M. Wagner, C. Veit, K.-C. Möller, J. Besenhard, M. Winter, M. WohlfahrtMehrens, C. Vogler, A. Hammouche, Ageing mechanisms in lithium-ion batteries, Journal of Power Sources 147 (1 - 2) (2005) 269 - 281. doi:10.1016/j.jpowsour.2005.01.006.

URL http://www.sciencedirect.com/science/ article/pii/S0378775305000832

[5] I. Bloom, B. Cole, J. Sohn, S. Jones, E. Polzin, V. Battaglia, G. Henriksen, C. Motloch, R. Richardson, T. Unkelhaeuser, D. Ingersoll, H. Case, An accelerated calendar and cycle life study of li-ion cells, Journal of Power Sources 101 (2) (2001) 238 - 247. doi : 10.1016/S0378-7753(01)00783-2.

URL http://www.sciencedirect.com/science/ article/pii/S0378775301007832

[6] M. Broussely, S. Herreyre, P. Biensan, P. Kasztejna, K. Nechev, R. Staniewicz, Aging mechanism in li ion cells and calendar life predictions, Journal of Power Sources 97-98 (2001) 13 - 21, proceedings of the 10th International Meeting on Lithium Batteries. doi: 10.1016/S0378-7753(01) 00722-4.

URL http://www.sciencedirect.com/science/ article/pii/S0378775301007224

[7] R. Wright, C. Motloch, J. Belt, J. Christophersen, C. Ho, R. Richardson, I. Bloom, S. Jones, V. Battaglia, G. Henriksen, T. Unkelhaeuser, D. Ingersoll, H. Case, S. Rogers, R. Sutula, Calendar- and cycle-life studies of advanced technology development program generation 1 lithium-ion batteries, Journal of Power Sources 110 (2) (2002) 445 - 470, pNGV. doi: $10.1016 / \mathrm{S} 0378-7753(02) 00210-0$.

URL http://www.sciencedirect.com/science/ article/pii/S0378775302002100

[8] A. Eddahech, O. Briat, E. Woirgard, J. Vinassa, Remaining useful life prediction of lithium batteries in calendar ageing for automotive appli- 
cations, Microelectronics Reliability 52 (9-10) (2012) 2438 - 2442, ¡ce:title ¿SPECIAL \{ISSUE\} 23rd \{EUROPEAN $\} \quad\{$ SYMPOSIUM $\} \quad\{\mathrm{ON}\}$ $\{$ THE $\} \quad\{$ RELIABILITY $\} \quad\{\mathrm{OF}\} \quad\{$ ELECTRON $\}$ DEVICES, \{FAILURE $\}$ PHYSICS $\}$ AAND $\}$ ANALY$\mathrm{SIS}_{\mathrm{i}} / \mathrm{ce}_{\text {title }}$. doi : 10.1016/j .microrel.2012.06.085. URL http://www.sciencedirect.com/science/ article/pii/S002627141200282X

[9] R. Spotnitz, Simulation of capacity fade in lithium-ion 615 batteries, Journal of Power Sources 113 (1) (2003) 72 - 80. doi:10.1016/S0378-7753(02)00490-1. URL http://www.sciencedirect.com/science/ article/pii/S0378775302004901

[10] J. Wang, P. Liu, J. Hicks-Garner, E. Sherman, 620 S. Soukiazian, M. Verbrugge, H. Tataria, J. Musser, P. Finamore, Cycle-life model for graphite-LiFePO4 cells, Journal of Power Sources 196 (8) (2011) 39423948. doi:10.1016/j.jpowsour.2010.11.134. URL http://www.sciencedirect.com/ 625 science/article/B6TH1-51KT8D2-3/2/ faf 150fd8d927be4e1d6b106893b13bc

[11] M. Ecker, N. Nieto, S. Käbitz, J. Schmalstieg, H. Blanke, A. Warnecke, D. U. Sauer, Calendar and cycle life study of li(nimnco)o2-based 18650 lithium-ion ${ }_{630}$ batteries, Journal of Power Sources 248 (2014) 839 851. doi:10.1016/j.jpowsour.2013.09.143.

URL http://www.sciencedirect.com/science/ article/pii/S0378775313016510

[12] O. Tebbi, Estimation des lois de fiabilité en mécanique 635 par les essais accélérés, Ph.D. thesis, Université d'Angers, thèse de Doctorat (2005).

URL https://tel.archives-ouvertes.fr/ tel-00009407

[13] A. Delaille, S. Grolleau, F. Duclaud, J. Bernard, 640 R. Revel, S. Pelissier, E. Redondo-Iglesias, J.-M. Vinassa, A. Eddahech, C. Forgez, M. Kassem, S. Joly, D. Porcellato, P. Gyan, S. Bourlot, M. OuattaraBrigaudet, Simcal project: Calendar aging results obtained on a panel of 6 commercial li-ion cells, in: 645 ECS Meeting Abstracts, no. 14, The Electrochemical Society, San Francisco, 2013, p. 1191.

URL http://ma.ecsdl.org/content/MA2013-02/14/ 1191.full.pdf

[14] M. Kassem, C. Delacourt, Postmortem analysis of calendar-aged graphite/lifepo4 cells, Journal of Power Sources 235 (2013) 159 - 171. doi:10.1016/j.jpowsour.2013.01.147.

URL http://www.sciencedirect.com/science/ article/pii/S037877531300205X

[15] A. Eddahech, O. Briat, J.-M. Vinassa, Strategy for lithium-ion battery performance improvement during power cycling, in: Industrial Electronics Society, IECON 2013 - 39th Annual Conference of the IEEE, 2013, pp. 6806-6811. doi:10.1109/IECON. 2013. 6700259.

[16] S. Grolleau, A. Delaille, H. Gualous, P. Gyan, R. Revel, J. Bernard, E. Redondo-Iglesias, J. Peter, Calendar aging of commercial graphite/lifepo4 cell - predicting capacity fade under time dependent storage conditions, Journal of Power Sources 255 (2014) 450-458. doi:10.1016/j.jpowsour.2013.11.098.

URL http://www.sciencedirect.com/science/ article/pii/S0378775313019411

[17] E. Redondo-Iglesias, P. Venet, S. Pelissier, Influence of the non-conservation of soc value during calendar age- ing tests on modelling the capacity loss of batteries, in: Ecological Vehicles and Renewable Energies (EVER), 2015 Tenth International Conference on, Montecarlo, Monaco, 2015, p. 5p. doi:10.1109/EVER.2015.7112987.

[18] M. Ecker, J. B. Gerschler, J. Vogel, S. Käbitz, F. Hust, P. Dechent, D. U. Sauer, Development of a lifetime prediction model for lithium-ion batteries based on extended accelerated aging test data, Journal of Power Sources 215 (2012) 248 - 257. doi:10.1016/j.jpowsour.2012.05.012.

URL http://www.sciencedirect.com/science/ article/pii/S0378775312008671

[19] IUPAC, Compendium of Chemical Terminology. Gold book., IUPAC, 2014. URL http://goldbook.iupac.org/index.html

[20] P. Kreczanik, P. Venet, A. Hijazi, G. Clerc, Study of supercapacitor aging and lifetime estimation according to voltage, temperature, and rms current, Industrial Electronics, IEEE Transactions on 61 (9) (2014) 4895-4902. doi:10.1109/TIE.2013.2293695.

[21] R. German, P. Venet, A. Sari, O. Briat, J.-M. Vinassa, Improved supercapacitor floating ageing interpretation through multipore impedance model parameters evolution, Power Electronics, IEEE Transactions on 29 (7) (2014) 3669-3678. doi:10.1109/TPEL. 2013.2279428.

[22] H. Dai, X. Zhang, W. Gu, X. Wei, Z. Sun, A semiempirical capacity degradation model of ev li-ion batteries based on eyring equation, in: Vehicle Power and Propulsion Conference (VPPC), 2013 IEEE, 2013, pp. 1-5. doi:10.1109/VPPC. 2013.6671660.

[23] R. Corless, G. Gonnet, D. Hare, D. Jeffrey, D. Knuth, On the Lambert $\mathrm{W}$ function, Advances in Computational Mathematics 5 (1) (1996) 329-359. doi:10.1007/ BF02124750.

URL $10.1007 /$ BF02124750

[24] M. A. Roscher, O. Bohlen, J. Vetter, Ocv hysteresis in li-ion batteries including two-phase transition materials, International Journal of Electrochemistry 2011. doi: $10.4061 / 2011 / 984320$. 